\title{
PRAKTYKI PEDAGOGICZNE W OPINII STUDENTÓW PEDAGOGIKI SPECJALNEJ
}

\begin{abstract}
Abstrakt: W artykule przedstawione zostały wyniki badań przeprowadzonych wśród studentek kierunku pedagogika specjalna na UMCS-ie w Lublinie. Badania dotyczyły realizacji praktyk pedagogicznych obowiązujących na tym kierunku. Ich wyniki zostały zaprezentowane dyrektorom i nauczycielom (opiekunom praktyk w placówkach) podczas spotkania, na którym omawiano kwestię związane podnoszeniem jakości praktyk przez UMCS. Miało to na celu wypracowanie wspólnych rozwiązań i postulatów, które pomogą w efektywny sposób zmodyfikować dotychczasowe działania w obszarze praktycznego przygotowania do zawodu nauczyciela-pedagoga specjalnego.
\end{abstract}

Słowa kluczowe: praktyka pedagogiczna, kształcenie nauczycieli, pedagogika specjalna, Uniwersytet Marii Curie-Skłodowskiej, badania

Praktyki pedagogiczne na kierunkach przygotowujących studentów do pracy nauczyciela-wychowawcy mają kluczowe znaczenie dla kształtowania ich kompetencji zawodowych i społecznych. Na przestrzeni lat wymiar praktyk ulegał zmianom. Stopniowo, ale dosyć systematycznie, zmniejszano liczbę zajęć praktycznych, np. wycieczek programowych, zajęć terenowych. Ograniczając znacząco kontakt studenta z prawdziwymi problemami szkolnymi, z uczniami, ich trudnościami, różnorodnymi zachowaniami i reakcjami, sukcesami, kształciliśmy tak naprawdę młodego człowieka, który nie był wystarczająco przygotowany do pracy.

Stosunkowo niedawno weszły w życie nowe standardy kształcenia nauczycieli zamieszczone w Rozporzadzeniu Ministra Nauki i Szkolnictwa Wyższego z dnia 17 stycznia 2012 r. w sprawie standardów kształcenia przygotowującego do wykonywania zawodu nauczyciela. Przepisy określają: 
1) efekty kształcenia w zakresie:

- wiedzy merytorycznej i metodycznej,

- wiedzy pedagogicznej i psychologicznej (w tym także wychowania) z uwzględnieniem przygotowania do pracy z uczniami o specjalnych potrzebach edukacyjnych,

- przygotowania do stosowania technologii informacyjnej,

- znajomości języka obcego,

2) czas trwania studiów oraz studiów podyplomowych,

3) wymiar i sposób organizacji praktyk.

Kształcenie przygotowujące do wykonywania zawodu nauczyciela prowadzone będzie w ramach trzech modułów obowiązkowych, obejmujących przygotowanie merytoryczne do nauczania przedmiotu (prowadzenia zajęć), psychologiczno-pedagogiczne oraz dydaktyczne. Zdobyte w ten sposób kwalifikacje zawodowe można będzie rozszerzyć o moduły fakultatywne dotyczące nauczania kolejnego przedmiotu (prowadzenia zajęć) oraz pedagogiki specjalnej (Rozporządzenie Ministra Nauki i Szkolnictwa Wyższego z dnia 17 stycznia 2012 r.).

Nowe podejście do kształcenia przyszłych nauczycieli polega na obowiązku zrealizowania przez nich trzech modułów:

- pierwszego, obejmującego zajęcia związane z danym kierunkiem studiów, np. historia, matematyka, biologia czy wychowanie przedszkolne;

- drugiego, związanego z przygotowaniem pedagogiczno-psychologicznym uwzględniającym poszczególne etapy edukacyjne (przedszkole i szkoła podstawowa, gimnazjum, szkoła ponadgimnazjalna) oraz obowiązek umiejętności poznania uczniów o szczególnych potrzebach, także uczniów zdolnych, niepełnosprawnych czy przewlekle chorych;

- trzeciego, dotyczącego dydaktyki (ogólnej oraz dydaktyki przedmiotowej).

Przewiduje się też dwa moduły fakultatywne, w ramach których student będzie mógł wybrać sobie przygotowanie do nauczania drugiego przedmiotu (prowadzenia zajęć), co odpowiada modułowi czwartemu (60 godzin zajęć i 60 godzin dodatkowych praktyk), lub w zakresie pedagogiki specjalnej, odpowiadającemu modułowi piątemu (dodatkowo 210 godzin zajęć z przygotowania psychologiczno-pedagogicznego i dydaktyki specjalnej oraz 120 godzin praktyk). Ogólna liczba godzin praktyk zawodowych w ramach pierwszych trzech modułów kształcenia wynosi 150 (Śliwerski 2012).

Wprowadzenie nowych standardów kształcenia nauczycieli nałożyło na uczelnie wyższe obowiązek dostosowania dotychczasowych siatek dydaktycznych do wymogów rozporządzenia. Modułowy charakter kształcenia wymusił większą liczbę godzin praktyk na studiach w zakresie pedagogiki specjalnej, co sprzyja bardziej 
rzetelnemu i profesjonalnemu przygotowaniu studentów do wykonywania bardzo odpowiedzialnego zawodu nauczyciela-pedagoga specjalnego.

\section{ORGANIZACJA BADAŃ}

Aby sprostać tym wymogom i podnieść jakość praktyk, koordynatorzy praktyk z UMCS-u zaprojektowali i zrealizowali na przełomie 2012/2013 roku następujące badania diagnostyczne:

- Praktyki studenckie na kierunku pedagogika specjalna UMCS w opinii dyrektorów i opiekunów praktyk w placówkach kształcenia specjalnego

- Praktyki studenckie na kierunku pedagogika specjalna UMCS w opinii studentów

Głównym celem badań było poznanie opinii zarówno interesariuszy zewnętrznych, czyli dyrektorów i nauczycieli, jak i studentów I i II stopnia studiów stacjonarnych na temat realizacji praktyk pedagogicznych na kierunku pedagogika specjalna.

W pierwszej części badań uczestniczyło 63 pedagogów pełniących funkcję opiekunów praktyk w placówkach kształcenia specjalnego na terenie Lublina i Świdnika. Szczegółowe wyniki dotyczyły trzech zagadnień: satysfakcji z pełnienia funkcji opiekuna praktyk studenckich, oceny merytorycznego i formalnego przygotowania studentów do praktyki i zaangażowania w pełnienie obowiązków praktykanta oraz oceny planowania i realizacji praktyk studenckich na UMCS-ie, w tym współpracy między instytucjami. Całościowy opis badań, a także wynikające z nich wnioski zamieściła dr Renata Zubrzycka w artykule Praktyki studenckie na kierunku pedagogika specjalna UMCS w Lublinie w opinii opiekunów praktyk w placówkach kształcenia specjalnego (Zubrzycka 2012).

Niniejsze opracowanie poświęcone jest drugiej grupie badanych - studentom.

Główny problem badawczy sformułowano w następujący sposób: jakie są opinie studentów pedagogiki specjalnej na temat realizacji praktyk pedagogicznych na tym kierunku na UMCS-ie w Lublinie?

Wskazano również problemy szczegółowe i ujęto je w formę pytań:

1. Jakie są opinie badanych studentów dotyczące ilości, czasu trwania i miejsca odbywania praktyk pedagogicznych?

2. Jakie zaskakujące sytuacje w placówkach miały miejsce w czasie odbywania praktyk przez studentów?

3. Jak badani studenci oceniają opiekę ze strony placówki, w której odbywali praktykę pedagogiczną?

4. Jak według opinii badanych studentów można ulepszyć system odbywania praktyk obowiązujących na UMCS-ie? 
W badaniach zastosowano metodę sondażu diagnostycznego wraz z techniką ankiety i skonstruowanym samodzielnie kwestionariuszem składającym się z 29 pytań.

Badaniami zostali objęci wszyscy studenci tego kierunku, którzy odbyli co najmniej jedną praktykę. Łącznie w badaniach wzięło udział 286 studentów: ze specjalności oligofrenopedagogika 127, ze specjalności tyflopedagogika 58 i ze specjalności pedagogika resocjalizacyjna 101 (rysunek 1). Ponieważ jednak ta ostatnia do tej pory nie była specjalnością nauczycielską, analizowano jako grupę docelową 185 studentek oligofrenopedagogiki i tyflopedagogiki. W badaniu uczestniczyły same kobiety w wieku 20-26 lat.

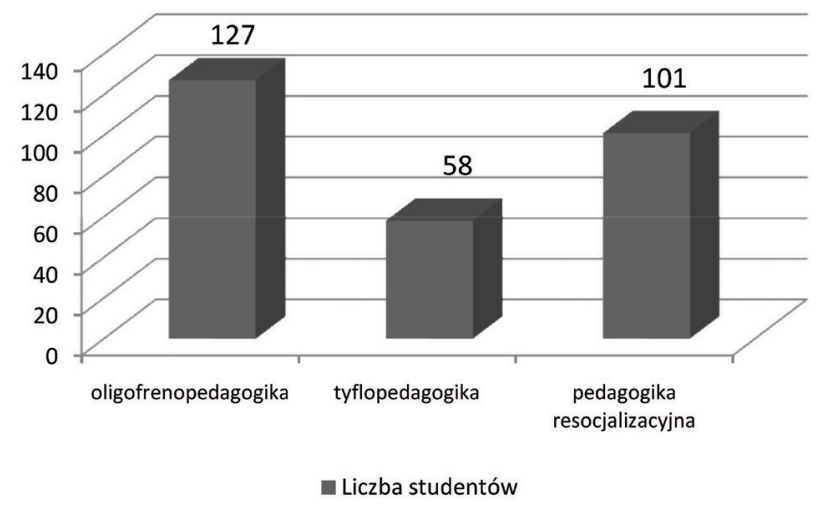

Rysunek 1. Podział na specjalności

\section{WYNIKI I INTERPRETACJA BADAŃ WŁASNYCH}

\section{Ilość, czas trwania i miejsce odbywania praktyk}

Studentki odbyły dotychczas od 1 do 10 praktyk, wliczając specjalności dodatkowe. Mniej niż $1 / 4$, czyli $24 \%$ badanych nie jest zadowolona $\mathrm{z}$ liczby odbytych praktyk (rysunek 2).

Zauważalna jest pewna tendencja - im bliżej końca studiów, tym wyższy poziom niezadowolenia z liczby odbywanych praktyk. Studentki postulują zwiększenie ilości zajęć praktycznych. Zbliżając się ku końcowi studiów, wykazują coraz większą świadomość specyfiki pracy pedagoga specjalnego, dlatego chcą być jak najlepiej przygotowane i przez to bardziej atrakcyjne dla ewentualnego pracodawcy.

70\% studentek cały założony czas praktyki odbywała w placówce. Zdarzały się jednak sytuacje, kiedy praktyka nie była doprowadzona do końca lub studentki brały udział w innych zajęciach poza placówką. Tylko 60 osób (32\%) pozostało 
w placówce po praktyce i pracuje jako wolontariusz. Być może część oczekuje takich propozycji ze strony placówki. Obserwujemy obecnie rozkwit wolontariatu. Prawdopodobnie studentki chętnie zostałyby w placówkach, gdyby częściej padały takie propozycje.

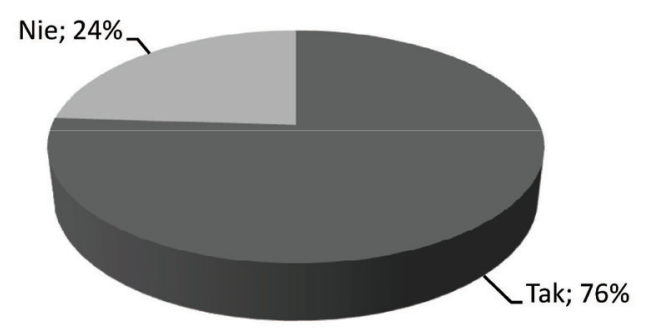

Rysunek 2. Zadowolenie z liczby odbytych praktyk

Prawie $95 \%$ badanych stwierdza, że podczas praktyk nabyło przydatne w przyszłej pracy zawodowej umiejętności. Nieco ponad połowa (53\%) studentek nawiązała kontakty, które umożliwią odbycie stażu lub zdobycie pracy. Te stwierdzenia wyraźnie sygnalizują, że praktyki pedagogiczne są niezwykle potrzebne, aby ułatwić kończącym studia młodym nauczycielom wejście na rynek pracy.

Studentki odnotowały, że wykonywały podczas praktyk czynności dodatkowe, nieobjęte programem praktyk. Prawie $25 \%$ podaje, że prace, którymi zajmowały się w placówce, wykraczały poza plan praktyki. Studentki wykonywały czynności pielęgnacyjne, prowadziły zajęcia pod nieobecność nauczyciela, kserowały dokumenty, robiły gazetki szkolne, przygotowywały nauczycielowi materiały, zostawały samodzielnie z uczniami na dzień lub kilka dni, pełniły obowiązki nauczyciela wspomagającego, dyżurowały na przerwach i sprzątały. Prowadzi to do wniosku, że możliwość wykonywania wyżej wymienionych czynności (będących codziennością każdego nauczyciela) powinna być co najmniej zasygnalizowana podczas zajęć metodycznych przygotowujących do odbycia praktyki.

Około $15 \%$ studentek miało problemy ze znalezieniem miejsca odbywania praktyk. Jako najczęstsze przyczyny podają zbyt dużą ilość chętnych, za mało placówek chcących przyjąć studentów oraz brak płatności za praktyki. O ile w placówkach ogólnodostępnych (których jest bardzo dużo) tego typu utrudnienia raczej nie występują, o tyle w przypadku placówek specjalnych staje się to poważnym problemem. Placówek specjalnych czy specjalistycznych jest relatywnie mniej niż ogólnodostępnych. Przez kilka lat nauczyciele z tych instytucji przyjmujący studentów na praktykę byli wynagradzani przez uczelnie. Wynagrodzenie to, choć symboliczne, zostało jednak zniesione. Ponieważ ilość praktyk wzrosła zgodnie 
z nowymi standardami kształcenia nauczycieli, zobligowanych do ich odbycia studentów jest również więcej. Te czynniki sprawiają, że w środowisku nauczycielskim narasta zrozumiały opór i niechęć.

90\% studentek chciałoby odbywać praktyki przede wszystkim w placówkach specjalistycznych związanych z kierunkiem studiów. Około 13\% chciałoby również poznać pracę w placówkach ogólnodostępnych.

\section{Zaskakujące sytuacje w czasie odbywania praktyk}

Jak podają studentki, zdarzały się w placówkach różne zaskakujące sytuacje. Nie były na nie przygotowane, co również daje wskazówkę, o czym należy studentów informować przed podjęciem praktyk.

Wymieniane zaskakujące sytuacje ze strony nauczycieli:

- zostawienie na kilka godzin samej studentki z uczniami (85\%),

- bezradność nauczycieli wobec uczniów,

- brak wiedzy nauczycieli o niepełnosprawnościach,

- lekceważący stosunek nauczycieli do studentek,

- niechęć nauczycieli do studentek.

Powyższe sytuacje rzeczywiście należy przemyśleć. Dlatego też zostały zaprezentowane na spotkaniu z interesariuszami zewnętrznymi, by wspólnie je omówić i wyeliminować zdarzenia budzące wątpliwości.

\section{Ze strony uczniów:}

- atak epilepsji,

- konflikty z rodzicami,

- agresja uczniów,

- zachowania uczniów o charakterze seksualnym,

- uczniowie z niepełnosprawnościami sprzężonymi.

Zderzenie z rzeczywistością szkolną może okazać się trudne dla wielu studentów $\mathrm{z}$ uwagi na to, że w ramach zajęć dydaktycznych prowadzonych na uczelni nacisk położony jest na zachowanie pedagoga wobec ucznia. Chcemy wykształcić nauczyciela kompetentnego pod względem merytorycznym, metodycznym, wyposażonego w umiejętności komunikacyjne i pedagogiczno-psychologiczne. Niewielu wykładowców przygotowuje studentów na spotkanie z uczniem, który nie zawsze zachowuje się w sposób akceptowany społecznie. Dlatego warto zastanowić się, czy zetkniecie z uczniem agresywnym, jawnie pobudzonym seksualnie, ze sprzężonymi niepełnosprawnościami nie będzie zbyt dużym szokiem dla praktykanta. Może warto ich uprzedzić, że takie zachowania w szkołach specjalnych, w pracy z osobami z różnymi niepełnosprawnościami mogą się jednak zdarzyć. 


\section{Ze strony studenta:}

- brak wiedzy jak posługiwać się sprzętem dla niewidomych (tyflopedagogika),

- prowadzenie zajęć z dziećmi z zaburzeniami wzroku i niepełnosprawnością intelektualną (tyflopedagogika),

- długie godziny przygotowań (materiały, konspekty itd.).

32\% praktykantek miało trudności w prowadzeniu zajęć (zachowanie dyscypliny wśród uczniów, niestosowne zachowania uczniów, ingerencja nauczyciela, nieprzygotowanie przez uczelnię do odbycia praktyki).

Opinie studentek dają rzeczywisty obraz samopoczucia i subiektywnego postrzegania siebie w sytuacji dydaktyczno-wychowawczej. Analiza wyszczególnionych uwag prowadzi do wniosku, że należy położyć większy nacisk na demonstrację i sposób wykorzystania najnowszych pomocy edukacyjnych w pracy tyflopedagoga.

Wydaje się oczywiste z punktu widzenia nauczyciela, że przybywające obecnie do placówek dzieci będą cierpiały na różne współtowarzyszące zaburzenia, m.in. będą niepełnosprawne intelektualnie. Jednak student tyflopedagogiki rzadko bierze pod uwagę taką ewentualność, więc dobrze byłoby bardziej wyartykułować zagadnienia sprzężonych niepełnosprawności, które mogą wystąpić u uczniów.

Budowanie warsztatu pracy pedagoga specjalnego to rzeczywiście długie godziny przygotowań. Napisanie dobrego, elastycznego, przejrzystego konspektu czy przygotowanie własnoręcznie pomocy dydaktycznych w większej ilości może na początku sprawiać nieco trudności młodym nauczycielom. Dlatego wydaje się tak ważne, by ćwiczyć na zajęciach te czynności, by uzmysłowić studentom, że nie tylko ich ogromna wiedza teoretyczna jest potrzebna do pracy z uczniem, ale i zgromadzone w czasie studiów doświadczenie, umiejętności zastosowania specjalnych metod czy dyscyplinowania uczniów oraz zestawy pomocy.

\section{Opieka w placówce}

W kwestionariuszu ankiety znalazły się również pytania dotyczące opiekuna praktyki w placówce. Ponad $\mathbf{8 0 \%}$ studentek przyznaje, że opiekun umożliwił zapoznanie się ze specyfiką funkcjonowania placówki. Zaledwie 12 osób, czyli nieco ponad 6\%, podaje, że opiekun praktyki z placówki miał do nich zły, lekceważący bądź obojętny stosunek. Ponad $\mathbf{9 0 \%}$ studentek przyznaje, że opiekunowie wykazywali bardzo dobry lub dobry stosunek do nich oraz udzielali wsparcia merytorycznego i formalnego podczas praktyki. Opiekun dokonał szczegółowego podsumowania i udzielił konkretnych wskazówek na przyszłość (33\%), dokonał ogólnego podsumowania (53\%), nie podsumował praktyki (14\%). W ogólnym rozrachunku $95 \%$ ankietowanych podaje, że mogła liczyć na pomoc opiekuna praktyki z placówki. 
Studentki wymieniają następujące rodzje pomocy:

- pomoc w poznaniu uczniów/wychowanków - 70\%,

- wsparcie w wyborze tematu i doborze metod dydaktycznych i wychowawczych do zajęć prowadzonych samodzielnie - 55\%,

- wsparcie w formułowaniu celów zajęć - 38\%,

- pomoc w rozwiązywaniu konkretnych problemów wychowawczych w trakcie praktyki $-46 \%$.

Z wymienionych uwag wynika, że większość studentek chętnie korzysta z pomocy opiekunów praktyki w placówce, co jest oczywiście uzasadnione. Praktyka pedagogiczna jest dalszym etapem kształcenia. Budującym faktem jest życzliwość, pomoc i przekazywana przez opiekunów wiedza. Odpowiedzialność za wykształcenie nowych pedagogów specjalnych spoczywa na barkach zarówno nauczycieli akademickich, jak i nauczycieli-praktyków. Im ściślej będziemy ze sobą współpracować, tym lepiej przygotujemy następnych nauczycieli, co w konsekwencji przekłada się na bardziej efektywny sposób kształcenia i wychowania dzieci oraz młodzieży z niepełnosprawnością.

$\mathrm{W}$ odpowiedziach dotyczących prowadzonych przez studentki zajęć dominuje uczucie zadowolenia: 75\% studentek deklaruje aktywny udział uczniów w swoich zajęciach, $19 \%$ wskazuje, że uczniowie mieli neutralny stosunek do zajęć, a tylko 3 osoby wymieniają niechętny lub lekceważący stosunek uczniów do zajęć podczas praktyki.

\section{Prezentacja wyników interesariuszom zewnętrznym}

W dniu 4 lutego 2013 roku w Instytucie Pedagogiki odbyło się spotkanie z interesariuszami zewnętrznymi, czyli dyrektorami i opiekunami praktyk z placówek współpracujących z UMCS-em. Spotkanie zostało zorganizowane i poprowadzone przez koordynatorów praktyk z Zakładów Psychopedagogiki Specjalnej oraz Socjopedagogiki Specjalnej UMCS. Celem spotkania była wymiana opinii i doświadczeń dotyczących jakości przygotowania praktyk studenckich przez opiekunów z UMCS-u, przygotowania merytorycznego i formalnego studentów - przyszłych pedagogów specjalnych, a także realizacji praktyk. Uczestnikom spotkania przedstawiono wyniki badań dotyczące przede wszystkim: oceny czasu trwania i organizacji praktyk, przygotowania praktycznego i merytorycznego studentów UMCS-u, problemów w czasie trwania praktyki zgłaszanych przez studentów.

Studentki biorące udział w badaniu zaproponowały kilka sposobów udoskonalenia systemu odbywania praktyk związanych z:

1. Czasem trwania praktyk:

- zwiększenie ilość godzin praktyk, 
- organizowanie przez wykładowców wyjścia do placówek,

- przywrócenie praktyk śródrocznych,

- zwiększenie ilości praktyk w specjalistycznych placówkach,

- wprowadzenie obowiązku rocznego wolontariatu,

- organizowanie praktyk w roku akademickim, a nie w czasie wolnym studenta.

2. Dokumentacją i przygotowaniem:

- uszczegółowienie programów praktyk,

- prezentacja uzupełniania dzienniczka praktyk,

- ujednolicenie wzorów konspektów,

- wprowadzenie do programów nauczania więcej zadań praktycznych, przygotowujących do prowadzenia zajęć z dziećmi.

3. Finansami:

- pokrycie kosztów (dojazdy, noclegi) studenta,

- zapłata nauczycielom za opiekę nad praktykantem.

Zaprezentowane wnioski z badań, uwagi krytyczne oraz propozycje zmian sformułowane przez badanych opiekunów praktyk stały się punktem wyjścia do dyskusji nad aktualnym stanem i projektowanymi działaniami na rzecz optymalizacji jakości kształcenia studentów na kierunku pedagogika specjalna. Wypracowano następujące propozycje zmian w zakresie:

Regulaminu, dokumentacji i czasu trwania praktyki:

1. Wydłużenie czasu praktyk do 3 tygodni, aby zwiększyć szanse studentów na dokonanie obserwacji dzieci w czasie różnych form aktywności edukacyjnej.

2. Uszczegółowienie regulaminu praktyk oraz zwiększenie liczby godzin zajęć samodzielnie prowadzonych przez studentów oraz poświęconych obserwacji i nawiązaniu indywidualnego kontaktu $\mathrm{z}$ wychowankami.

3. Zmniejszenie liczby godzin zajęć hospitowanych na rzecz pełnienia przez studenta funkcji nauczyciela wspomagającego.

4. Przywrócenie hospitacji zajęć w ciągu roku akademickiego i zajęć metodycznych prowadzonych na terenie placówek (od 2 lat studenci odbywają wyłącznie praktyki ciągłe i nie są przygotowani do nawiązania kontaktu z niepełnosprawnymi uczniami, co utrudnia realizację celów praktyki, szczególnie na studiach I stopnia, które są studiami zawodowymi).

5. Ujednolicenie dzienniczka praktyk i określenie kryteriów oceny studenta.

6. Ujednolicenie wymagań dotyczących tworzenia dokumentacji praktyk (schemat konspektu zajęć).

\section{Organizacji praktyk:}

1. Poprawa komunikacji opiekuna z uczelni z opiekunem na terenie placówki 
(wskazany byłby bezpośredni lub telefoniczny kontakt przynajmniej jeden raz w czasie trwania praktyk).

2. Podniesienie stawek wynagrodzenia dla opiekuna praktyk w placówce kształcenia specjalnego.

3. Terminowe wypłaty wynagrodzenia i uproszczenie formularza umowy dotyczącej praktyki.

\section{Przygotowania studentów:}

1. Zwiększenie kreatywności i zaangażowania studentów przez wprowadzenie aktywizujących metod ich kształcenia w toku zajęć akademickich.

2. Przygotowanie studentów do pracy $\mathrm{z}$ dzieckiem $\mathrm{z}$ niepełnosprawnością sprzężoną (w aktualnie obowiązującej siatce przedmiot rewalidacja osób ze złożoną niepełnosprawnością umieszczony jest w szóstym semestrze, podczas gdy wszystkie praktyki na studiach I stopnia odbywane są przed jego rozpoczęciem) (Zubrzycka 2012).

\section{PODSUMOWANIE}

Analiza postulatów studentek oraz wniosków i propozycji zmian wypracowanych na spotkaniu z interesariuszami zewnętrznymi pokazuje, że istnieją wyraźne wskazania do pracy dydaktycznej podczas zajęć uczelnianych. Propozycje te skłaniają do częściowej modyfikacji programów kształcenia studentów. Należałoby zwrócić szczególną uwagę na aspekty praktyczne w realizacji metodyk pracy z uczniem z niepełnosprawnościami.

Wiele z poruszonych zagadnień, wraz z wymaganą modyfikacją siatek dydaktycznych, zostało już uwzględnionych w programach kształcenia na uczelniach wyższych. W ramach stałego podnoszenia jakości nauczania oraz dążenia do kompleksowej realizacji efektów kształcenia prowadzący zajęcia starają się brać pod uwagą nie tylko potrzeby samych studentów, ale także rozległy, systematycznie badany rynek pracy i oczekiwania przyszłych pracodawców. Wszystkie te działania zmierzają do jednego, nadrzędnego celu - takiego wykształcenia nowych pedagogów specjalnych, by w możliwie najlepszy i najpełniejszy sposób byli w stanie przygotować swoich uczniów, wychowanków, podopiecznych, czyli osoby z niepełnosprawnością, do samodzielnego, godnego życia.

\section{LITERATURA}

Rozporządzenie Ministra Nauki i Szkolnictwa Wyższego z dnia 17 stycznia 2012 r. $w$ sprawie standardów kształcenia przygotowującego do wykonywania zawodu nauczyciela (Dz.U. 2012 poz. 131) [pozyskano z: 
http://www.kn.uw.edu.pl/images/20120117_standardy_ksztalcenia_dla_nauczycieli.pdf]

Śliwerski B., 2012, Standardy kształcenia nauczycieli wyszły z cienia resortowych biurek, opublikowano: http://sliwerski-pedagog.blogspot.com/2012/01/standardy-ksztacenia-nauczycieli-wyszy.html [dostęp: 28.01.2018].

Zubrzycka R., 2014, Praktyki studenckie na kierunku pedagogika specjalna UMCS $w$ Lublinie w opinii opiekunów praktyk w placówkach kształcenia specjalnego. W: J. Bogucki, A. Bochniarz, A. Grabowiec (red.), Przez praktyki do praktyki: $w$ stronę innowacyjności w kształceniu nauczycieli, cz. 3: Pedagogiczne przygotowanie przyszłych nauczycieli. Lublin, Wydawnictwo UMCS, 157-167.

\section{PEDAGOGICAL INTERNSHIP ACCORDING TO STUDENTS OF SPECIAL EDUCATION}

Abstract: The article presents the results of studies conducted among female students of special education at the Maria Curie-Skłodowska University in Lublin. The research concerned serving pedagogical internship required for this specialization. The results were presented to headmasters and teachers (internship supervisors) at a meeting during which the issue of increasing the quality of internships was discussed. The aim was to develop common solutions and postulates which can effectively modify current activities in the field of the practical preparation of future special education teachers.

Key words: pedagogical practice, teacher education, special education, Maria Curie-Skłodowska University, studies 